\title{
The Permanent Refugee Crisis in the Federal Republic of Germany, 1949-
}

\author{
Lauren Stokes
}

\begin{abstract}
This article puts forced migration at the center of the Federal Republic's history. Forced migration to Germany has often been understood as an unprecedented crisis, but, far from being an aberration, such migration has been a necessary component of the classic legitimating narratives of the Federal Republic and a crucial support for its postwar "economic miracle." The official reception of forced migrants has been structured by a categorical distinction between genuine refugees and ersatz "economic refugees." The former are lauded for their economic contributions to Germany, whereas those alleged to have migrated mainly for economic reasons are condemned as fraudulent opportunists. These categories have been continually transposed onto new groups of forced migrants, whose arrival is invariably grasped as a crisis. The unfolding of refugee "crises" and their resolutions have continually shown the artificiality of the distinction between genuine and economic refugees—while simultaneously redrawing it.
\end{abstract}

Dieser Aufsatz rückt Zwangsmigration ins Zentrum der Geschichte der Bundesrepublik Deutschland. Zwar wurde Zwangsmigration nach Deutschland oft als eine beispiellose Krise wahrgenommen, doch letztlich war solche Migration keine Abweichung, sondern eine notwendige Komponente des klassischen Legitimitätsnarrativ der Bundesrepublik, die gleichzeitig einen wesentlichen Beitrag zum „Wirtschaftswunder” der Nachkriegszeit leistete. In der offiziellen Rezeption wurden Zwangsmigranten kategorisch in ,echte' Flüchtlinge und ,Wirtschaftsflüchtlinge' unterteilt. Während man die erstgenannte Gruppe oft für ihre wirtschaftlichen Beiträge lobte, wurden diejenigen, die angeblich nur aus wirtschaftlichen Gründen immigriert sind, als betrügerische Opportunisten verurteilt. Diese Kategorien wurden kontinuierlich auf neue Gruppen von Zwangsmigranten übertragen, deren Ankunft ausnahmslos als Krise begriffen wurde. Die Entfaltung von Flüchtlings-,,Krisen” und deren Lösungen zeigen wie künstlich diese Unterscheidung zwischen, echten' Flüchtlingen und ,Wirtschaftsflüchtlingen' ist - eine Unterscheidung, die dadurch gleichzeitig auch neu getroffen wird.

HE number of asylum applicants arriving in the European Union increased sharply in the first half of 2015, and many countries chose to react by shutting their borders and refusing to accept further applications for asylum. Under the Dublin Regulation, which came into force in 1997, the first European country reached by an asylum seeker is responsible for examining their application. Germany announced in August 2015 that it would stop enforcing the Dublin Regulation for citizens of

For their helpful feedback, I would like to thank participants in the 2016 "New Narratives of the Federal Republic" seminar and in the 2017 "The Demos and the Market" seminar at the German Studies Association annual conferences in San Diego and in Atlanta. Astrid M. Eckert, Frank Biess, and the two anonymous reviewers all gave invaluable feedback on earlier drafts of this piece. Robin Bates read multiple drafts and clarified crucial parts of the argument. Research for this article was funded primarily by the German Chancellor Fellowship of the Alexander von Humboldt Foundation and by a travel grant from the Central European History Society. 
Syria - the largest but, by no means, the only source of the spike in asylum applicants - and thus effectively agreed to process Syrians who had been shut out of the asylum process in other states. By the end of 2015, over one million new asylum seekers had been registered in Germany. This sequence of events is reshaping German politics. The far-right party Alternative for Germany (AfD) entered the Bundestag after the 2017 elections, having received the third-highest number of votes running on a promise to undo the state's response to the refugee crisis.

When speakers declare a migratory situation to be a "crisis," they suggest not just that the situation is a departure from what is normal, but also that it is untenable in the long term, and that it requires a decisive solution. ${ }^{1}$ While the language of crisis evokes the idea of a situation without precedent, this article argues that forced migration must be at the center of any new narrative of the history of the Federal Republic of Germany. The Federal Republic has been confronted continuously with forced migrants since 1945 and has also found ways to incorporate these forced migrants as labor power. At particular moments, the ongoing migration that has been a structural feature of the Federal Republic has been suddenly rediscovered as a crisis.

Politicians from across the ideological spectrum have proposed solutions that focus on better regulation of migration, arguing that Germany, and, by extension, Europe, can better filter "desirable" from "undesirable" migrants within mixed migration flows. These arguments often rest on a distinction between the "genuine refugee" and the "economic migrant" (or even the "economic refugee" [Wirtschaftsflüchtling] $).^{2}$ In order to preserve the ability to grant asylum to "genuine refugees" who are fleeing political persecution, the state must exclude "economic migrants," who are supposedly deceptively seeking material gain, a category described by one scholar as "the most reviled of asylum seekers of the global era."3

Despite the demonization of those who are purportedly "economic refugees," the "genuine refugees" are also consistently described as potential demographic and specifically economic assets. In the summer of 2015, Der Spiegel was one of many media outlets to report that the Syrian refugees could be "an opportunity to help companies grow," whereas the German Institute for Economic Research, a think tank based in Berlin, enthused that, even if the initial costs were heavy, the refugees would undoubtedly benefit the economy in the long term by reinvigorating an aging German workforce. ${ }^{4}$

\footnotetext{
${ }^{1}$ My thinking on "crisis" is influenced by Rüdiger Graf, Moritz Föllmer, and Per Leo, "Einleitung: Die Kultur der Krise in der Weimarer Republik," in Die 'Krise' der Weimarer Republik. Zur Kritik eines Deutungsmusters (Frankfurt/Main: Campus Verlag, 2005), 11-31; Adam McKeown, Melancholy Order: Asian Migration and the Globalization of Borders (New York: Columbia University Press, 2008).

${ }^{2}$ The distinction between "migrant" and "refugee" has become the primary way of indexing this difference in contemporary politics. Whereas the AfD, for example, distinguishes between "refugees from war" and "irregular migrants," the Green Party program specifically rejects the charge that most refugees are "economic refugees" (Wirtschaftsflüchtlinge). See "Das Grundsatzprogramm der Alternative für Deutschland," Alternative for Germany, adopted May 1, 2016 (https://www.afd.de/grundsatzprogramm/), p. 118; "Grüne Argumente von A bis Z," Green Party, June 28, 2016 (https://www.gruene.de/themen/ gruene-themen-von-a-bis-z.html), p. 63.

${ }^{3}$ Catherine Dauvergne, Making People Illegal: What Globalization Means for Migration and Law (Cambridge: Cambridge University Press, 2008), 65.

${ }^{4}$ Markus Dettmer, Carolin Katschak, and Georg Ruppert, "German Companies See Refugees as Opportunity," Spiegel Online, Aug. 27, 2015 (http://www.spiegel.de/international/germany/refugeesare-an-opportunity-for-the-german-economy-a-1050102.html); Marcel Fratzscher and Simon Junker,
} 
When politicians stress refugees' ability to work - while simultaneously insisting that tough policies are needed to keep out opportunistic "economic refugees" - they reiterate a paradoxical dichotomy that has characterized not only the German but also the international refugee regime. It has always been crucial that new arrivals not only be willing and able to work, but also that they never intend to work. The category "economic refugee" describes a deceitful individual who blurs the distinction between the political and the economic out of self-interest. It stigmatizes in foreigners precisely those features considered desirable in citizens: the desire to work, the will to self-improvement, and the willingness to invest one's own human capital where it will produce the highest return. " "Real" refugees are supposed to be so afraid for their lives that they can scarcely function, whereas people suspected of making rational choices fall out of the tolerated category of "refugee" and into the stigmatized category of the "economic refugee," precisely by displaying independence and making purposeful calculations. ${ }^{6}$ In the current international refugee regime, states that accept refugees are expected to use economic logic to make their selection, but the refugees themselves must be without economic motivation.

While this distinction between the economic and the genuine refugee is common across Europe, the Federal Republic's unique constitutional guarantee of asylum means that it has long received more asylum seekers than anywhere else in Europe, and, as a result, that it has also played a decisive role in shaping European and international refugee regimes. ${ }^{7}$ This article traces the ways in which the Federal Republic's permanent refugee crisis has repeatedly redrawn the distinction between desirable and undesirable migrants. ${ }^{8}$ Forced migrants have always played a key role in providing a mobile labor force, while the figure of the "economic refugee" has repeatedly functioned as the villainous outsider used to justify shifts in policy. As the category of the "economic refugee" attaches itself to new groups of migrants, the Federal Republic continually produces new narratives of crisis, ensuring that each new migration is treated as if it were the first of its kind rather than the latest chapter in an ongoing history.

\section{Born in Crisis:}

\section{Displaced Persons and Expellees in the Early Federal Republic}

The Basic Law of the Federal Republic, adopted in 1949, included one of the world's most generous guarantees of asylum in Article 16: "Persons persecuted on political grounds shall enjoy the right of asylum." Described by Klaus Bade as "Germany's historic response to the experience of National Socialism," this constitutional guarantee of asylum represented a new

\footnotetext{
"Integration von Flüchtlingen: eine langfristig lohnende Investition," DIW Wochenbericht 45 (2015): 1083-88.

${ }^{5}$ Quinn Slobodian made this point in his comments on the panel "New Approaches to Race and Migration in Postwar Germany" at the 2015 German Studies Association annual meeting in Washington, D.C.

${ }^{6}$ On how "fear" functions as a political category, see Peter Nyers, Rethinking Refugees: Beyond States of Emergency (New York: Routledge, 2006), 43-68.

${ }^{7}$ Guy S. Goodwin-Gill, The Refugee in International Law (Oxford: Clarendon Press, 1983), 226, 229-31; Matthew J. Gibney, The Ethics and Politics of Asylum: Liberal Democracy and the Response to Refugees (Cambridge: Cambridge University Press, 2004), 85-106.

${ }^{8}$ For more detail on the practice of granting asylum in both German states after 1945, see Patrice G. Poutrus, "Zuflucht im Nachkriegsdeutschland. Politik und Praxis der Flüchtlingsaufnahme in Bundesrepublik und DDR von den späten 1940er Jahren bis zur Grundgesetzänderung im vereinten Deutschland von 1993," in Handbuch Staat und Migration in Deutschland seit dem 17. Jahrhundert, ed. Jochen Oltmer (Berlin: Walter de Gruyter, 2016), 853-93.
} 
emphasis on protection, especially when compared to the Weimar Republic, where roughly one million refugees from the Russian Revolution and the upheavals of World War I had found themselves in legal limbo. ${ }^{9}$ But the Basic Law's guarantee also prompted an unanswered question: what does it mean to be persecuted on specifically political grounds?

Because World War II had left millions of people displaced from their homes, the lawmakers of the Federal Republic were not the only people grappling with questions about the right of refuge in the postwar era. Eight million forced laborers from across Europe, including Jewish survivors of concentration and death camps, found themselves on German territory. Although roughly seven million returned to their former residences within the first year, another million remained in defeated Germany because they were unwilling or unable to return home. Germany had also lost one-third of its pre-1937 territory to Poland and Czechoslovakia, which were, along with other states, forcibly expelling a diverse group of ethnic Germans from the new countries of Eastern Europe to the occupation zones. By 1950, 12.5 million ethnic German expellees were registered in the two German states.

International organizations defined the "refugee" for the postwar world through their engagement with this diverse population of displaced people in the German occupation zones. The Federal Republic's own definition of those entitled to asylum- - "persons persecuted on political grounds" - was, in fact, far more capacious than the international definition of a "refugee" codified two years later by the United Nations. The 1951 Convention Relating to the Status of Refugees defined the refugee as a person who,

as a result of events occurring before 1 January 1951 and owing to well-founded fear of being persecuted for reasons of race, religion, nationality, membership of a particular social group or political opinion, is outside the country of his nationality and is unable or, owing to such fear, is unwilling to avail himself of the protection of that country; or who, not having a nationality and being outside the country of his former habitual residence as a result of such events, is unable or, owing to such fear, is unwilling to return to it. ${ }^{10}$

Scholars have examined this definition in great detail, drawing attention to its focus on "well-founded fear," its strict temporal boundaries, the limited categories of persecution that it enumerates, its privileging of political freedoms over economic rights, and its emphasis on the refugee subject as either unable or "unwilling" to return home. ${ }^{11}$ The definition also reflected the composition of a Central Europe undergoing a novel

\footnotetext{
${ }^{9}$ Klaus J. Bade, Ausländer, Aussiedler, Asyl: Eine Bestandsaufnahme (Munich: C. H. Beck, 1994), 94. For refugees in interwar Europe, see Michael R. Marrus, The Unwanted: European Refugees in the Twentieth Century (Oxford: Oxford University Press, 1985), 51-121. For Weimar Germany, see Jochen Oltmer, Migration und Politik in der Weimarer Republik (Göttingen: Vandenhoeck \& Ruprecht, 2005); Annemarie H. Sammartino, The Impossible Border: Germany and the East, 1914-1922 (Ithaca, NY: Cornell University Press, 2010).

${ }^{10}$ United Nations Convention Relating to the Status of Refugees (https://www.unhcr.org/ 3b66c2aa10).

${ }^{11}$ Among others, see T. Alexander Aleinikoff, "State-Centered Refugee Law: From Resettlement to Containment," Michigan Journal of International Law 14, no. 1 (1992): 120-38; Kazimierz Bem, "The Coming of a 'Blank Cheque'-Europe, the 1951 Convention, and the 1967 Protocol," International Journal of Refugee Law 16, no. 4 (2004): 609-27; Gerard Daniel Cohen, In War's Wake: Europe's Displaced Persons in the Postwar Order (Oxford: Oxford University Press, 2012); Andrew Paul Janco, "'Unwilling': The One-Word Revolution in Refugee Status, 1940-51," Contemporary European History 23, no. 3 (2014): 429-46; Tara Zahra, The Great Departure: Mass Migration from Eastern Europe and the Making of the Free World (New York: W. W. Norton, 2016), 181-216.
} 
process of ethnic homogenization. By defining the refugee as a person whose nationality necessarily did not match their current location, the new international definition explicitly excluded the 12.5 million ethnic German expellees now living in the German occupation zones. Roughly 43 percent had not been German citizens before the war, and, in fact, up to 40 percent of these "ethnic Germans" did not identify themselves as such in a 1946 survey. ${ }^{12}$ Their self-understanding did not matter: their forced migration "marked the drawing of a new political border," and the fact that others identified them as German meant that they were now inside the country of their nationality and therefore written out of the postwar international humanitarian regime. ${ }^{13}$ West German officials would protest for over a decade that these expellees should be recognized as refugees under the 1951 Convention, to no avail in the end. ${ }^{14}$

This situation created a kind of zero-sum competition in the Federal Republic among the different groups of forced migrants, most of whom found themselves living in rural areas with intact housing stock. In hundreds of small towns and villages across Germany, locals were forced to share their already scarce resources with foreigners who had the potential to be recognized as refugees under international law, and with expelled ethnic Germans considered, by the same international standards, already to be "home."15 West Germans used the term displaced person (DP) to designate "an undesirable mass of foreigners burdening a country already struggling with its 'own' refugee problem," and to use the term refugee (Flüchtling) as "a synonym for specifically German refugees and expellees," creating a kind of inversion of the international definition. ${ }^{16}$ As Anna Holian and Atina Grossmann have both argued, the distinction between "refugees" and "DPs" racialized the former population as part of the German community and the latter as external to it, a distinction that gained its coherence from preexisting anti-Slavic and antisemitic attitudes. ${ }^{17}$ In the longterm, this coexistence of multiple groups of refugees arguably abetted the social integration of the ethnic German expellees: despite tensions between locals and expellees, they were often able to unite in common cause against the DPs and the drain on resources they allegedly represented. ${ }^{18}$

To be recognized as "genuine refugees," DPs had to convince officials from the United Nations Relief and Rehabilitation Administration (UNRRA) and later the International Refugee Organization (IRO) that they were not motivated by hopes of economic gain;

\footnotetext{
${ }^{12}$ Gaëlle Fisher, "Heimat Heimstättensiedlung: Constructing Belonging in Postwar West Germany," German History 35, no. 4 (2017): 569; R. M. Douglas, Orderly and Humane: The Expulsion of the Germans after the Second World War (New Haven, CT: Yale University Press, 2012), 314.

${ }^{13}$ Manuel Borutta and Jan C. Jansen, "Comparing Vertriebene and Pieds-Noirs: Introduction," in Vertriebene and Pieds-Noirs in Postwar Germany and France: Comparative Perspectives, ed. Manuel Borutta and Jan C. Jansen (London: Palgrave MacMillan, 2016), 9. Also see Goodwin-Gill, The Refugee in International Law, 57.

${ }^{14}$ Volker Ackermann, Der "echte" Flüchtling. Deutsche Vertriebene und Flüchtlinge aus der DDR 1945-1961 (Osnabrück: Universitätsverlag Rasch, 1995), 51-64.

${ }^{15}$ Adam R. Seipp, Strangers in the Wild Place: Refugees, Americans, and a German Town, 1945-1952 (Bloomington, IN: Indiana University Press, 2013), 8.

${ }^{16}$ Anna Holian, "A Missing Narrative: Displaced Persons in the History of Postwar West Germany," in Migration, Memory, and Diversity: Germany from 1945 to the Present, ed. Cornelia Wilhelm (New York: Berghahn, 2017), 38. Emphasis in original.

${ }^{17}$ Holian, "Missing Narrative"; Atina Grossmann, Jews, Germans, and Allies: Close Encounters in Occupied Germany (Princeton, NJ: Princeton University Press, 2007), 257-60.

${ }^{18}$ Seipp, Strangers, esp. 97-141.
} 
this created "strong incentives to overemphasize the political nature of their flight." 19 Convincing aid workers of political motives was necessary to attain refugee status, but, in order to leave that status behind and start a new life, DPs then had to switch their strategies and demonstrate their economic utility. The DP camps became "battlegrounds for laborers," with labor recruiters from the United States, Canada, Australia, and the United Kingdom sorting through DPs to find men who were able to perform manual labor and single women who could be recruited as domestic servants. ${ }^{20}$ Recruiters were not looking for well-educated refugees. Intellectuals and doctors tended to be extremely difficult to place; Canada, for instance, rejected women with postsecondary education. ${ }^{21}$ In addition, countries including Canada and the United States were reluctant to resettle families that were expected to burden the welfare system. As a result, refugees who were sick or disabled also had a difficult time leaving the camps, as did those who were unwilling to leave behind their disabled family members. ${ }^{22}$

Whereas the DPs needed to be economically useful in order to leave Germany, the expellees needed to be economically useful in order to rebuild Germany. With one in every five residents a newly arrived expellee, the Federal Republic was forced to find a way to use its own refugees - unacknowledged as such by the emergent international refugee regimeas human capital. Many of the expellees initially found themselves in the rural parts of the Western zones-particularly in Schleswig-Holstein, Lower Saxony, and Bavaria-before moving on to industrial regions, where demand for their labor was higher. Some 1.7 million moved between Länder (federal states) of their own volition in the 1950s; the state undertook four projects to encourage the resettlement of another one million, roughly three-quarters of whom were moved to either North Rhine Westphalia or BadenWürttemberg. The state stepped in to influence internal migration patterns, redirecting the population in response to the needs of the labor market. ${ }^{23}$

By the late 1950s, the architects of Germany's postwar economic miracle frequently recognized that the refugee population had contributed to its success. As Ludwig Erhard, the Federal Republic's first minister of economics, wrote in his 1958 book, Prosperity for All, "the countless refugees who during the first post-war years exacerbated the terrible plight of our people, now in a time of full employment have become an asset." 24 Erhard built on ideas previously articulated by economist Friedrich Edding, who had used his position at the Kiel Institute for the World Economy to argue that the expellees would be an asset to the German economy if their presence led to "a breakdown of all those old traditional and parochial restrictions which curtail free competition." 25 These economists saw the presence of refugees as an asset for the German workforce: without their own land or capital, and

\footnotetext{
${ }^{19}$ Cohen, In War's Wake, 51.

${ }^{20}$ Ibid., 104-8; Kathleen Paul, Whitewashing Britain: Race and Citizenship in the Postwar Era (Ithaca, NY: Cornell University Press, 1997), 75.

${ }^{21}$ Tony Judt, Postwar: A History of Europe since 1945 (New York: Penguin, 2005), 31.

${ }^{22}$ Ruth Balint, "Children Left Behind: Family, Refugees, and Immigration in Postwar Europe," History Workshop Journal 82, no. 1 (2016): 151-72.

${ }^{23}$ Siegfried Bethlehem, Heimatvertriebung, DDR-Flucht, Gastarbeiterzuwanderung: Wanderungsströme und Wanderungspolitik in der Bundesrepublik Deutschland (Stuttgart: Klett-Cotta, 1982), 48-80.

${ }^{24}$ Ludwig Erhard, Prosperity Through Competition, trans. Edith Temple Roberts and John B. Wood (New York: Frederick A. Praeger, 1958), ix.

${ }^{25}$ Friedrich Edding, The Refugees as a Burden, a Stimulus, and a Challenge to the West German Economy (The Hague: Martinus Nijhoff, 1951), 36.
} 
highly motivated to take any job available, they served as what Karl Marx might have called a "doubly free" economic asset. These early economic evaluations of the German refugees influenced later arguments that they had served as a modernizing force. ${ }^{26}$ Economic historians have argued that the expellee population shaped the economic miracle: expellees allowed the Federal Republic to expand its industrial base while making relatively low investments in human capital. ${ }^{27}$

The definition of the expellee was codified by the May 1953 Federal Law on Expellees and Refugees (Bundesvertriebenengesetz). This law created a legal framework not only for the economic and social integration of the expellees already in Germany, but also for the continuing migration of ethnic Germans to the Federal Republic. The 1953 law guaranteed that the Federal Republic would provide refuge for "repatriates" (Aussiedler), i.e., ethnic Germans from Communist countries who were welcomed because they had presumably experienced "ethnically-based pressure to emigrate [Vertreibungsdruck]." 28 German ethnicity did not suffice to claim repatriate status, as only those Germans who could claim that they had been forced to leave Communist countries were eligible. Ethnic Germans in Denmark or France could not migrate as repatriates, but ethnic Germans from China or Albania could. ${ }^{29}$ Although the category was initially expected to exhaust itself quickly, repatriates continued to arrive for decades, their fluctuating numbers depending on the Eastern bloc's willingness to issue exit permits. Yugoslavia had a relatively liberal emigration policy, compared to other Communist countries, and the high numbers of Yugoslavian repatriates - and the fact that they could leave relatively easily-led to suspicions of economic opportunism in the early $1960 \mathrm{~s} .{ }^{30}$ The number of repatriates rose most significantly in the late 1980s, as more and more Communist countries loosened their requirements for

\footnotetext{
${ }^{26}$ Meryn McLaren, “'Out of the Huts Emerged a Settled People’: Community-Building in West German Refugee Camps,” German History 28, no. 1 (2010): 22.

${ }^{27}$ This argument is made most strongly by Tamás Vonyó, The Economic Consequences of the War: West Germany's Growth Miracle after 1945 (Cambridge: Cambridge University Press, 2018). Also see Werner Abelshauser, Deutsche Wirtschaftsgeschichte von 1945 bis zur Gegenwart (Bonn: Bundeszentrale für politische Bildung, 2011), 324-25; Bethlehem, Wanderungsströme und Wanderungspolitik; Gerold Ambrosius, "Der Beitrag der Vertriebenen und Flüchtlinge zum Wachstum der westdeutschen Wirtschaft nach dem Zweiten Weltkrieg," Jahrbuch für Wirtschaftsgeschichte 2 (1996): 39-71; Dierk Hoffmann, "Binnenwanderung und Arbeitsmarkt. Beschäftigungspolitik unter dem Eindruck der Bevölkerungsverschiebung in Deutschland nach 1945," in Vertriebene in Deutschland. Interdisziplinäre Perspektiven und Forschungsperspektiven, ed. Dierk Hoffmann, Marita Krauss, and Michael Schwartz (Munich: Oldenbourg, 2000), 219-325.

${ }^{28}$ Amanda Klekowski von Koppenfels, "The Decline of Privilege: The Legal Background to the Migration of Ethnic Germans," in Coming Home to Germany? The Integration of Ethnic Germans from Central and Eastern Europe in the Federal Republic, ed. David Rock and Stefan Wolff (New York: Berghahn, 2002), 102-18. My thanks to Stefanie Woodward for pointing me to resources on the Aussiedler and for sharing a chapter from her forthcoming dissertation.

${ }^{29}$ Christian Joppke and Zeev Rosenhek, "Contesting Ethnic Immigration: Germany and Israel Compared," in Diasporic Homecomings: Ethnic Return Migration in Comparative Perspective, ed. Takeyuki Tsuda (Stanford, CA: Stanford University Press, 2009), 82-83.

${ }^{30}$ Jannis Panagiotidis, "Sifting Germans from Yugoslavs: Co-ethnic Selection, Danube Swabian Migrants, and the Contestation of Aussiedler Immigration in West Germany in the 1950s and 1960s," in Migrations in the German Lands, 1500-2000, ed. Jason Poley, Jared Coy, and Alexander Schunka (New York: Berghahn, 2016), 209-26; Christopher A. Molnar, Memory, Politics, and Yugoslav Migrations to Postwar Germany (Bloomington: Indiana University Press, 2019).
} 
an exit visa. ${ }^{31}$ The establishment of the "repatriate" as a category of forced migrant underlines the importance of the category of the "genuine refugee": in order not to be suspected of economic opportunism, ethnic German repatriates needed to be able to say that they were fleeing Communist rule because of their ethnic identity.

The two categories of forced migrants who shaped the early days of the Federal Republic both found themselves required to be economically useful, even though they were defined by their supposed lack of interest in economic gain. The initial groups of expellees were integrated into German society by emphasizing their hard work and by serving as the first mobile labor reserves of the so-called economic miracle. Meanwhile, displaced persons seeking to leave the German occupation zones were required to feign economic disinterest, denying any possible economic motives to authorities even as their ability to perform labor became their ticket out of the camps and to a new life.

\section{Finding the "Genuine Refugee" among Emigrants from the Soviet Zone}

In the early years of the Federal Republic, ethnic German expellees overlapped with another group of Germans on the move, namely, the roughly 3.5 million people who had left the Soviet zone of occupation for the Western zones before 1961. One-third of these Soviet zone emigrants were, in some sense, "refugees" twice over, since many of the expellees who had initially lived in the Soviet zone chose to move yet again in hopes that conditions would be better in the West. ${ }^{32}$

What the East German state experienced as an emigration crisis, the West German state perceived as a refugee crisis. Both understood the mass movement across the border as an existential threat that needed to be mastered. The East reacted by sealing the inter-German border, constructing the Berlin Wall, and criminalizing emigration. The Federal Republic's response to the refugee crisis also shaped the nascent state. In the first years after 1949, there was a serious debate about whether West Germany should accept refugees from the Soviet occupation zone when it was already struggling to integrate millions of German expellees.

Both arguments against accepting Soviet zone emigrants can only be understood in the context of the mass expulsion of ethnic Germans from Eastern Europe. First, many people in the Federal Republic feared that mass emigration of ethnic Germans from the Soviet zone would enable the transformation of the area into a permanent Soviet colony devoid of Germans, ultimately to be lost to the Soviet Union just as East Prussia had been lost to Poland. ${ }^{33}$ The second argument against accepting Soviet zone emigrants was the fact that

\footnotetext{
${ }^{31}$ Jannis Panagiotidis, "Staat, Zivilgesellschaft und Aussiedlermigration 1950-1989," in Handbuch Staat und Migration in Deutschland seit dem 17. Jahrhundert, ed. Jochen Oltmer (Berlin: Walter de Gruyter, 2016), 895-929.

${ }^{32}$ For a comprehensive view of East German policy towards expellees, see Michael Schwartz, Vertriebene und 'Umsiedlerpolitik': Integrationskonflikte in den deutschen Nachkriegs-Gesellschaften und die Assimilationsstrategien in der SBZ/DDR 1945-1961 (Munich: R. Oldenbourg Verlag, 2004); idem, "Assimilation versus Incorporation: Expellee Integration Policies in East and West Germany after 1945," in Vertriebene and Pieds-Noirs, 73-94.

${ }^{33}$ Ackermann describes this as a "horror vacui" argument; see Ackermann, Der 'echte' Flüchtling, 97-99. It is also mentioned in Helge Heidemeyer, Flucht und Zuwanderung aus der SBZ/DDR 1945/ 1949-1961: Die Flüchtlingspolitik der Bundesrepublik Deutschland bis zum Bau der Berliner Mauer (Düsseldorf: Droste Verlag, 1994), 31-33; Sascha Schieß1, "Das Tor zur Freiheit”: Kriegsfolgen, Erinnerungspolitik und humanitärer Anspruch im Lager Friedland (1945-1970) (Göttingen: Wallstein, 2016), 314-24.
} 
the Federal Republic's resources were already strained. Bavarian radio journalist Walter von Cube famously referred to the acceptance of Eastern zone refugees as an act of "suicidal humanitarianism," whereas Ernst August Farke, a representative of the Deutsche Partei (German Party) in Lower Saxony, used an arresting metaphor in the Bundestag to argue against their acceptance: "We find ourselves in a lifeboat. The boat is overflowing, and the more who come aboard, the more it is in danger of capsizing and sinking." 34 Officials such as Wolfgang Jaenicke, state secretary for refugee affairs in Bavaria, believed that the refugee crisis had, in fact, been engineered by the Soviet occupation authorities in order to undermine the Western Allies, a rumor that circulated widely among the general public. ${ }^{35}$

Another common argument against accepting arrivals from the East was the belief that the majority were emigrating for disreputable reasons - which meant that "the problem of the 'misuse' of the right to asylum [had] emerged in German-German relations even before the Federal Republic was founded."36 In March 1950, the Ministry for All-German Questions believed that only 15 percent of the emigrants from the East were "genuine refugees" fleeing political persecution. ${ }^{37}$ Officials who looked at East German emigrants did not see them as desirable citizens, but rather as criminals trying to avoid imprisonment, as sex workers who hoped to find clients among the occupation forces, as young men skipping out on unwanted pregnancies, and as people who wanted to shirk the hard work of reconstruction and take it easy in the "Golden West." 38 Some Western border guards acted on these stereotypes, forcing "illegal border crossers" back into the Soviet zone. Informing him that "we have enough of your sort here," one border guard in the town of Neustadt even drove a self-declared refugee "like a cow back over the border."39

Though unaware at the time that this particular emergency would continue for nearly forty years, the fledgling Federal Republic established the Emergency Reception Procedure (Notaufnahmeverfahren) for Soviet zone emigrants in August 1950. The procedure was intended to distinguish those emigrants who were "genuine refugees" from those who were economic opportunists. Those accepted as "political refugees" were entitled to special privileges. Those who belonged to a second group of emigrants were accepted as citizens of the Federal Republic "on discretion" and given residence permits, but without the same

\footnotetext{
${ }^{34}$ Von Cube quoted in Eric H. Limbach, "Unsettled Germans: The Reception and Resettlement of East German Refugees in West Germany, 1949-1961” (PhD diss., Michigan State University, 2011), 84-85; Milo Dor and Reinhard Federmann, "Einleitung," in Sprung in die Freiheit: Berichte über die Ursachen, Begleitumstände und Folgen der Massenflucht aus der Sowjetischen Besatzungszone Deutschlands (Ulm: Knorr \& Hirth Verlag, 1953), 7. Farke is quoted in Ackermann, Der 'echte' Flüchtling, 96. Farke spoke from experience, since he had been the head of the Refugee Committee in Lower Saxony. See Arne Hoffrichter, "Uelzen und die Abgelehnten-Das Flüchtlingsdurchgangslager Uelzen-Bohldamm und die Folgen der SBZ/DDR-Flucht als lokales Problem 1949/1950," in Flüchtlingslager im Nachkriegsdeutschland. Migration, Politik, Erinnerung, ed. Henrik Bispinick and Katharina Hochmuth (Berlin: Ch. Links, 2014), 205.

${ }^{35}$ Edith Sheffer, Burned Bridge: How East and West Germans Made the Iron Curtain (Oxford: Oxford University Press, 2011), 68; Dor and Federmann, Sprung in die Freiheit, 8.

${ }^{36}$ Ackermann, Der 'echte' Flüchtling, 94.

${ }^{37}$ Ibid., 86-96.

${ }^{38}$ Ibid., 79-82; Sheffer, Burned Bridge, 66-70; McLaren, “'Out of the Huts,"” 33-34.

${ }^{39}$ The cited example comes from Sheffer, Burned Bridge, 69. The Western Allies were, in fact, actively working to discourage illegal border crossing from East to West. See Sagi Schaefer, States of Division: Border and Boundary Formation in Cold War Rural Germany (Oxford: Oxford University Press, 2014), esp. 18-57.
} 
special privileges as those in the first group..$^{40}$ The final group of applicants was rejected because its members could not give a convincing explanation of the political persecution that had forced them to flee. Just as had been the case with DPs who had made their case to international organizations, Soviet zone emigrants who could only tell stories of economic hardship were not recognized as refugees deserving of assistance. The Federal Ministry for Expellees made this exclusion explicit in February 1951: "Economic grounds, without accompanying personal danger, will without exception not be considered as grounds for acceptance." 41

What happened to the East Germans whose claims to refugee status were rejected? The Federal Republic was unwilling to deport rejected applicants, since that would mean conceding sovereignty and legitimacy to the East German state. Although they were citizens of the Federal Republic, these rejected applicants also became some of the first "undocumented" migrants in the Federal Republic: they could not be deported, but they could not register their residence or receive permission to work. ${ }^{42}$ Suspected of economic motives, rejected refugees were legally excluded from the very labor market they had wanted to join.

The Federal Republic's attitude to East German refugees only changed after 1952, when the German Democratic Republic (GDR) responded to its emigration crisis by securing the German-German border. This ensured that the vast majority of people who wanted to enter the Federal Republic would do so through West Berlin. West Germany's ongoing refugee crisis suddenly became concentrated in the island city. Over one thousand new people arrived in West Berlin every day-31,613 in February 1953 alone. Because they could not receive the documents that would have allowed them to travel, rejected applicants were stuck in West Berlin and unable to move onward to the Federal Republic. As refugees continued to strain the city's resources, pressure grew to streamline and liberalize the procedure to relieve West Berlin. ${ }^{43}$

The sealing of the German-German border and the new visibility of the refugee problem in West Berlin contributed to a shift in public opinion about the new arrivals. In the West, the continuing flow of refugees from East Germany was increasingly depicted as proof of the illegitimate nature of the East German state, and the refugees themselves as deserving victims of totalitarianism rather than as dishonest opportunists. ${ }^{44}$ Despite these shifts in public perception, officials continued to object to the idea of a general amnesty for applicants whose claims had been rejected, fearing that this would only serve to stimulate economic emigration further. ${ }^{45}$

\footnotetext{
${ }^{40}$ Elke Kimmel analyzes these cases in “... war ihm nicht zuzumuten, länger in der SBZ zu bleiben.” DDRFlüchtlinge im Notaufnahmelager Marienfelde (Berlin: Metropol Verlag, 2009).

${ }^{41}$ Quoted in Limbach, "Unsettled Germans," 52.

${ }^{42}$ Rejected applicants are discussed in more detail in Hoffrichter, "Uelzen und die Abgelehnten"; Eric H. Limbach, "Provisional State, Reluctant Institutions: West Berlin's Refugee Service and Refugee Commissions, 1949-1952," Central European History 47, no. 4 (2014): 822-43.

${ }^{43}$ Ackermann, Der 'echte' Flüchtling, 104; Heidemeyer, Zuwanderung aus der SBZ/DDR, 134-64; Bethlehem, Wanderungsströme und Wanderungspolitik, 94; Limbach, "Unsettled Germans," 75.

${ }^{44}$ Astrid M. Eckert generously provided me with a draft of the chapter "The Making of the West German Borderlands, 1945-1955," from her forthcoming book, West Germany and the Iron Curtain; also see Heidemeyer, Zuwanderung aus der SBZ/DDR.

${ }^{45}$ Ackermann, Der 'echte' Flüchtling, 107-8; Heidemeyer, Zuwanderung aus der SBZ/DDR, 143-44.
} 
In May 1953, the Federal Constitutional Court issued a ruling that limited the state's previous ability to discourage emigration. The court ruled that, because those Germans living in the so-called Eastern zone were also citizens of the Federal Republic, the guarantee to freedom of movement, set forth in Article 11 of the Basic Law, also applied to them. This freedom of movement could not be restricted for any German citizen who had access to "adequate means of support." Most of these applicants had been rejected initially because their interrogators believed that they were coming to the West for solely economic reasons. But, after May 1953, these presumed opportunists discovered that their labor power was now an asset: if they could find a job in the Federal Republic, they could bypass the interrogation and use the job offer to receive a work permit and a residence permit. This court ruling thus turned the rejected into another group of "doubly free" workers, unconnected to property and exceptionally willing to move in order to take jobs considered undesirable by the native population of the Federal Republic. ${ }^{46}$ The refugees from the Soviet zone and later the GDR tended to be young, healthy, and often skilled. In fact, one historian has estimated that they represented roughly 2.6 billion deutschmarks (DM) worth of human capital each year, an addition to the West German labor force whose economic significance "cannot be overstated." 47 By the late 1950s, top officials at the Ministries of Economics and Labor acknowledged the key role that Soviet-zone emigrants played in providing a mobile labor force. ${ }^{48}$

After the May 1953 court ruling blunted the impact of rejection by allowing rejected applicants to work and travel, the Federal Ministry for Expellees also came to support a more liberal acceptance procedure for those leaving East Germany. Over the next eight years, fewer than 10 percent of all East German emigrants were rejected outright, and the vast majority of new arrivals were accepted as refugees and as residents of the Federal Republic "on discretion." ${ }^{49}$ Harald M., who fled in 1960, recalled that he had been accepted despite his failure to tell a story of persecution: "only when one came before an official ... who asked: 'Why did you leave the Soviet zone?'- then one began to think. Most thought for too long and the official wrote: 'Reason for flight: the general political and economic circumstances.' The person being questioned then only needed to nod." 50

People like Harald M. might have been easily accepted "on discretion," but they were also unlikely to be among the 25 percent of applicants who received the status of "political refugee" entitled to special privileges. ${ }^{51}$ Volker Ackermann has argued that, although one may be tempted to see the procedure after 1953 as a "farce," it was kept in place because it allowed the Federal Republic to "uphold the fiction of the 'genuine' political refugee." 52 Though refugees from the GDR could not be returned to their place of origin, officials remained reluctant to issue an open invitation to the discontented. Western authorities valued the interrogation for intelligence purposes, but they also

\footnotetext{
${ }^{46}$ Heidemeyer, Zuwanderung aus der SBZ/DDR, 164-67.

${ }^{47}$ Abelshauser, Deutsche Wirtschaftsgeschichte, 294-95.

${ }^{48}$ Bethlehem, Wanderungsströme und Wanderungspolitik, 85-87.

${ }^{49}$ Kimmel, DDR-Flüchtlinge, 70.

${ }^{50}$ Barbara Grunert-Bronnen, Ich bin Bürger der DDR und lebe in der Bundesrepublik (Munich: R. Piper \& Co, 1970), 112.

${ }^{51}$ Heidemeyer, Zuwanderung aus der SBZ/DDR, 231.

${ }^{52}$ Ackermann, Der 'echte' Flüchtling, 111.
} 
valued it, at least in part, as a deterrent. ${ }^{53}$ The continued insistence on an "emergency procedure" to separate the "genuine" refugee from the economic "opportunist" also supported the narrative that emigration from the East was a temporary crisis that necessitated a punctuated response, rather than an increasingly indispensable component of the Federal Republic's continued economic growth. The Federal Republic was coming to depend on GDR emigrants as a renewable resource of mobile labor.

\section{Maintaining Mobile Labor: Mediterranean Workers Vote with Their Feet}

When British journalist Robert Kee visited the Federal Republic in 1960, his guides were proud to show him an empty displaced persons camp from which all the former residents had finally been resettled. Kee felt his heart sink, however, when he noticed that, "on the other side of the road were three familiar ex-Hitler wooden-type barracks." Kee's guide stepped in to reassure him: "Those aren't refugees ... they're foreign workers, Italians mainly, imported to work in the Mercedes factory." 54 The explanation leads to further questions: with thousands of people still living in refugee camps in the late 1950s, why was the Federal Republic seeking to import yet more people? West German officials still seeking international recognition of their own refugee problem were forced to defend the decision to sign a labor recruitment contract with Italy in $1955 .{ }^{55}$ If the movement of refugees from East to West placed the state in a crisis, as its officials claimed, why did that same state also want to recruit additional foreign workers?

Foreigners already had begun, in fact, to self-mobilize and migrate in response to the continued demand within West Germany, as bilateral state contracts to recruit foreign workers were often state attempts to bring preexisting migratory patterns under state oversight. ${ }^{56}$ Italians were already obtaining work permits in the southern part of West Germany as early as 1952-three years before the first official recruitment agreement in $1955 .{ }^{57}$ Moroccans had begun to work in the Federal Republic as early as 1959, but Morocco and the Federal Republic only signed a bilateral agreement in $1963 .{ }^{58}$ A Spanish worker who arrived without a visa in early 1960 explained: "We needed no papers, no permission, nothing. You just began." 59 Spain and West Germany signed a bilateral agreement in March 1960 in order to be able to exercise slightly more control over Spanish labor migration. ${ }^{60}$

Meanwhile, the situation with regard to Soviet-zone labor was changing. The building of the Berlin Wall in August 1961 cut that source off overnight, most obviously

\footnotetext{
${ }^{53}$ Keith R. Allen, Interrogation Nation: Refugees and Spies in Cold War Germany (Lanham, MD: Rowman \& Littlefield, 2017); Bethlehem, Wanderungsströme und Wanderungspolitik, 81-87.

${ }^{54}$ Robert Kee, Refugee World (London: Oxford University Press, 1961), 51-52.

${ }^{55}$ Ackermann, Der 'echte' Flüchtling, 57.

${ }^{56}$ The idea of the "autonomy of migration" is most fully explored in Manuela Bojadžijev, Die windige Internationale: Rassismus und Kämpfe der Migration (Münster: Westfälisches Dampfboot, 2008); Serhat Karakayali, Gespenster der Migration. Zur Genealogie illegaler Einwanderung in der Bundesrepublik Deutschland (Bielefeld: transcript, 2008).

${ }^{57}$ Karakayali, Gespenster, 98.

${ }^{58}$ Ibid., 114-19.

${ }^{59}$ Stadtarchiv Nürnberg (StadtAN) F 21, Interview Nr. 266, July 2008.

${ }^{60}$ Carlos Sanz Díaz, "Clandestinos", "Illegales", "Espontáneos"... La emigración irregular de españoles a Alemania en el contexto de las relaciones hispano-alemanas, 1960-1973 (Madrid: Comisión Española de Historia de las Relaciones Internacionales, 2004).
} 
in Berlin-where over 56,000 people were no longer able to commute daily from the East to work in the West-but also in the rest of the Federal Republic, where employers could no longer rely on a steady stream of recently recognized East German refugees. The so-called guest worker program effectively replaced these workers as the next large-scale state scheme for making labor power mobile. Because the state had already stepped into the role of migration broker six years beforehand, there was no break in the flow of human capital. ${ }^{61}$

The Federal Republic was never fully in control of "guest worker" migration. Even after the bilateral agreement, roughly one-third of Spanish migration to West Germany continued to be "irregular," meaning that would-be migrant workers arrived in the Federal Republic without work visas. During the period of "full employment," West German employers actively encouraged this irregularity because it provided access to skilled workers and female workers whose visas Spanish authorities were reluctant to approve. ${ }^{62}$ In cities where employers were looking for labor, local Foreigners' Offices routinely approved the papers of migrants who entered irregularly, including almost any family member who wanted to work. ${ }^{63}$

Some foreign workers sought jobs in the Federal Republic in lieu of seeking asylum. The irregular route was particularly important for these workers. For example, authorities in Spain often rejected emigration applications from workers who were known to oppose Francisco Franco, fearing that they would be particularly susceptible to democratizing influences abroad. ${ }^{64}$ One guest worker from the Basque region recalled that he had emigrated, in part, because it was easier to speak his mother tongue in West Germany than in Franco's Spain. ${ }^{65}$ Turned down by the official recruitment program, politically active Spanish workers could still enter West Germany either on tourist visas or without papers, and then formally legalize themselves after the fact. ${ }^{66}$ The same dynamics applied elsewhere. In Portugal, many men signed up for the guest worker program to avoid the draft. ${ }^{67}$ One woman recalled that she had decided to become a guest worker because her father was a political prisoner in Greece. She had participated in Communist youth organizations, which made it impossible for her to advance in her career under the military junta. She and her husband decided to become guest workers in order to escape. As her daughter later explained, "my father had a good job and didn't have to leave. It was only the political situation that brought them to Germany." 68

In other words, just like those East Germans who wanted to start again in the "Golden West," foreign workers from the Mediterranean had a wide variety of economic, personal, and political reasons to "vote with their feet" for the Federal Republic. These heterogenous motives were repeatedly collapsed into a single category of "economic migrant" by the

\footnotetext{
${ }^{61}$ Bethlehem, Wanderungsströme und Wanderungspolitik, 80, 146-47.

${ }^{62}$ Sanz Díaz, "Clandestinos," 47-52, 63-65, 98-107.

${ }^{63}$ Lauren Stokes, "'Fear of the Family': Migration and Integration in West Germany, 1955-2000" (PhD diss., University of Chicago, 2016), 46-111.

${ }^{64}$ Sanz Díaz, "Clandestinos," 62.

${ }^{65}$ StadtAN F 21, Interview Nr. 19, March 2010.

${ }^{66}$ Sanz Díaz, "Clandestinos," 52-69.

${ }^{67}$ Elizabeth Buettner, Europe after Empire: Decolonization, Society, and Culture (Cambridge: Cambridge University Press, 2016), 303-4.

${ }^{68}$ StadtAN F 21, Interviews Nr. 184 and 185, Nov. 2009 and Feb. 2010.
} 
"guest worker" category. ${ }^{69}$ The West German state used the idea of the "guest worker" to reassure nervous constituents that only transient labor power was being recruited, without causing any durable change to the demography of the Federal Republic, while simultaneously undercutting any claim migrants might advance for social rights.

\section{Tolerating the "Economic Refugee": Socialist Citizens in the Federal Republic}

While citizens of Mediterranean countries were actively using both tourist visas and official recruitment agencies to move to the Federal Republic in order to work, some citizens of Central and Eastern European countries were using the asylum process to find their own path to the economic miracle. Christopher Molnar has shown that some officials were effectively "recruiting economic refugees from Yugoslavia," encouraging them to apply for asylum in order to access the labor market. ${ }^{70}$

Most of the people who applied for asylum in the Federal Republic in the 1950s and early 1960s came from Eastern and Southeastern Europe. ${ }^{71}$ Yugoslavians were consistently the largest single group among asylum seekers: in 1963, 91 percent of all new asylum seekers came from Yugoslavia alone. ${ }^{72}$ These asylum seekers had much in common with the East Germans who had fled across the German-German border. Officials believed that most asylum seekers from the Eastern bloc were inspired less by the fear of persecution than by the desire for economic gain. Despite purportedly illegitimate motivations, rejected asylum applicants from state-socialist countries were difficult to deport because of foreign policy considerations. Since 1955, the Hallstein Doctrine had dictated that the Federal Republic would not maintain diplomatic relationships with states that recognized the GDR - which meant that it could not easily deport people to any of these countries. ${ }^{73}$ Just as with the East Germans, the impossibility of deportation forced West Germany to tolerate rejected asylum seekers from socialism.

The specific term economic refugee appears to have developed in the late 1950s or early 1960s in order to describe such asylum seekers. Werner Kanein, then the foreigner expert in the Bavarian Interior Ministry, described it as a "deliberately ironic" term that "emerge[d] from practice" to describe asylum applicants with no claim to political persecution. ${ }^{74}$ The term was vigorously contested. For example, the American authors of the 1958

\footnotetext{
${ }^{69}$ For a discussion of the oddity of the phrase “guest worker," see Rita Chin, The Guest Worker Question in Postwar Germany (Cambridge: Cambridge University Press, 2007), 48-53. On the highly diverse individual motives, see Jennifer A. Miller, Turkish Guest Workers in Germany: Hidden Lives and Contested Borders, 1960s to 1980s (Toronto: University of Toronto Press, 2018).

${ }^{70}$ This section relies heavily on the generosity of Christopher Molnar, who provided me with an early draft of the chapter "Second-Class Refugees: The West German-Yugoslav Migration Regime and the Asylum Problem, 1953-1968," from his 2019 monograph, Yugoslav Migrations.

${ }^{71}$ Poutrus, "Zuflucht im Nachkriegsdeutschland," 887.

${ }^{72}$ Molnar, Yugoslav Migrations, 100.

${ }^{73}$ For more details on the global dimensions of the Hallstein doctrine, see William Glenn Gray, Germany's Cold War: the Global Campaign to Isolate East Germany, 1949-1969 (Chapel Hill: University of North Carolina Press, 2003).

${ }^{74}$ Werner Kanein, “Aktuelle Fragen des neuen Fremdenrechts," Deutsches Verwaltungsblatt 81, no. 17 (1966): 622. Also see Günter Schöppe, "Die 'Wirtschaftsflüchtlinge' im deutschen Asylverfahren," 2. Internationales Asyl-Colloquium. Garmisch-Partenkirchen 1964 (Cologne: Carl Heymanns Verlag, 1965), 87108.
} 
Zellerbach report on the European refugee crisis objected to the implication of the term, pointing out that many of the Yugoslavian emigrants were complaining about stateimposed atheism and political repression. ${ }^{75}$ Even as the authors of the report ascribed the Yugoslavians noneconomic motives for flight, they also argued that other states should be willing to accept the Yugoslavians primarily on economic grounds, since, "as potential immigrants," they were "one of the most desirable groups that ha[d] emerged since the end of the war." " Even the humanitarian critics of the new term economic refugee accepted the idea that states would act primarily out of economic motives.

In 1958, during a period of nearly full employment, the Interior Ministry accepted this economic logic when it decided that Eastern Europeans waiting for their claims to be adjudicated in the central refugee camp in Zirndorf-outside of Nuremberg in Bavaria—could receive a work permit and leave the camp as long as they could find a job outside of Bavaria. Like the transit camps for East German refugees, Zirndorf would become known as a reliable source of willing labor for West German employers, but when asylum seekers began to arrive in the Federal Republic already carrying company recruitment material, experts began to worry about the misuse of the asylum procedure. Werner Kanein of the Bavarian Interior Ministry complained that the refugee camp had become "a central employment agency for citizens of certain states, and the filing of an application for asylum only a necessary formal requirement," while refugee expert Günter Schöppe warned that "a foreigner who wants to work temporarily in the FRG can force the FRG to submit to his will." 77

The camp's neighbors saw Zirndorf not as a source of labor, but as a hotbed of criminal behavior and an unwanted presence in their town. In 1965, the Bavarian police responded to such concerns when they expelled from the camp four hundred asylum seekers suspected of being "economic refugees." News of the deportations alarmed other countries, including the United States and France, both of which prevailed on the United Nations High Commissioner for Refugees (UNHCR) to lodge an official protest with the Federal Republic. ${ }^{78}$ The international scandal precipitated by the expulsions found its way to the floor of the Bundestag in January 1966, when, in a rare exception to the usual silence about migration in the Bundestag, a routine question period became a debate about "economic refugees." 79 A total of fifteen representatives representing all three major parties took turns criticizing the category of the "economic refugee," as well as the deportations carried out by the Bavarian police. Fritz Büttner, a Social Democrat representing Moers in North Rhine-Westphalia, asked, "Who invented the term 'economic refugee'-a horrible term, by the way - and in this way created two kinds of refugees?" Hans Schäfer of the Interior Ministry responded by distancing himself from the term: "I share your opinion about this term ... I can't tell you who invented it, but it wasn't us. It developed in the

\footnotetext{
${ }^{75}$ The terms economic migrant and economic refugee are criticized in Refugees in Europe, 1957-1958: Report of the Zellerbach Commission on the European Refugee Situation (New York: Zellerbach Commission, 1958), 7, 58$61,64,68$.

${ }^{76}$ Ibid., 68.

${ }^{77}$ Kanein quoted in Molnar, Yugoslav Migrations, 117; Schöppe, “Die 'Wirtschaftsflüchtlinge,”” 107.

${ }^{78}$ Molnar, Yugoslav Migrations, 111-12; Thomas J. Hamilton, "Bavarian Village a Refugee Center: Expulsion of Many East Bloc Exiles Stirs Controversy,” New York Times, Nov. 7, 1965.

${ }^{79}$ Schönwälder, Einwanderung, 362.
} 
press or somewhere like that." 80 Herbert Wehner, the chairman of the Social Democratic fraction and a former member of the German Communist Party (KPD), met with universal acclaim when he argued: "What is called economy in Communist-ruled countries is so tightly linked with politics and persecution, that our bureaucracy should not put the burden of proof on the refugee to show what he is." ${ }^{81}$ According to Wehner's logic, communism had perverted the natural separation between the political and the economic, and those who were fleeing it were necessarily refugees as a result.

A few days after this discussion, the Interior Ministry issued guidelines stating that, from now on, rejected asylum seekers from the socialist countries would be extended even more courtesy than rejected East Germans had once received: they would not be deported, and would also be permitted to work legally. ${ }^{82}$ This official shift in policy initially excluded Yugoslavians because, in contrast to other socialist citizens, they had other legal routes into the Federal Republic. They could try to find an employer who was willing to sponsor them for a work visa, or they could enter on a tourist visa and then attempt to regularize their status. When Foreign Minister Willy Brandt negotiated a bilateral labor recruitment agreement with Yugoslavia in 1968, there were already over one hundred thousand Yugoslavians living in the Federal Republic, mostly on expired tourist visas or employersponsored work visas. ${ }^{83}$ The bilateral recruitment agreement served West German interests by helping employers to access skilled laborers and female laborers. ${ }^{84}$ The agreement also serves as an illustration of the fact that migration movements that establish themselves extralegally can, and frequently do, achieve official status. In this case, a migration that had first been experienced as a "crisis" of "economic refugees" became part of a well-regulated routine within a decade.

With Yugoslavians incorporated through the "guest worker" program and other refugees from socialism officially tolerated and allowed to work, the term economic refugee was rarely applied to people from the Eastern bloc after 1966. ${ }^{85}$ Key officials such as Ludwig Adenauer, the secretary of the minister of the interior in North Rhine-Westphalia, continued to believe that the vast majority of rejected asylum seekers were, in fact, better understood as "illegal guest workers." 86 Despite these suspicions, their origins behind the Iron

\footnotetext{
${ }^{80}$ Deutscher Bundestag, Plenarprotokoll 5/16, Jan. 26, 1966, 614-15. For the history of terms about asylum and refugee status, see Klaus J. Bade, "Zur Karriere und Funktion abschätziger Begriffe in der deutschen Asylpolitik," Aus Politik und Zeitgeschichte 65, no. 25 (2015): 3-8.

${ }^{81}$ Deutscher Bundestag, Plenarprotokoll 5/16, Jan. 26, 1966, 612.

${ }^{82}$ Ursula Münch, Asylpolitik in der Bundesrepublik Deutschland. Entwicklung und Alternativen, $2 \mathrm{nd}$ ed. (Opladen: Leske + Budrich, 1993), 54-60; Poutrus, "Zuflucht im Nachkriegsdeutschland," 878-79.

${ }^{83}$ Molnar, Yugoslav Migrations; Knortz, Diplomatische Tauschgeschäfte, 140-43; Kaja Shonick, "Politics, Culture, and Economics: Reassessing the West German Guest Worker Agreement with Yugoslavia," Journal of Contemporary History 44, no. 4 (2009): 719-36.

${ }^{84}$ Monika Mattes, "Gastarbeiterinnen" in der Bundesrepublik: Anwerbepolitik, Migration und Geschlecht in den 50er bis 70er Jahren (Frankfurt/Main: Campus Verlag, 2005), 51-55.

${ }^{85}$ Astrid Bröker and Jens Rautenberg, Die Asylpolitik in der Bundesrepublik Deutschland unter besonderer Berücksichtigung des sogenannten 'Asylmißbrauchs' (Berlin: Express Edition, 1986), 141-42; Simone Wolken, "Das Grundrecht auf Asyl als Problem der Rechtspolitik," Zeitschrift für Ausländerrecht und Ausländerpolitik 2 (1986): 59; Martin Wengeler, "Multikulturelle Gesellschaft oder Ausländer raus? Der sprachliche Umgang mit der Einwanderung seit 1945," in Kontroverse Begriffe. Geschichte des öffentlichen Sprachgebrauchs in der Bundesrepublik Deutschland, ed. Georg Stötzel and Martin Wengeler (Berlin: De Gruyter, 1995), 738.

${ }^{86}$ Bundesarchiv (BArch) B 106/38055, "Konferenz der Innenminister und Senatoren für Inneres der Länder. Innenministerkonferenz am 27/28.1.1966 in Saarbrücken.”
} 
Curtain had enabled them, in the court of public opinion, successfully to transmute economic motives into political motives and thus to be removed from the stigmatized category of the "economic refugee."

\section{Nach dem Boom: \\ Excluding the "Economic Refugee" from the Labor Market}

The category of the "economic refugee" attached itself to a new population in the 1970s as mass unemployment and underemployment became a structural feature of the Western European economy. ${ }^{87}$ In 1973, the Federal Republic announced a ban on further labor migration, which came as a shock to labor migrants and would-be labor migrants. ${ }^{88}$ Although many foreign workers chose to leave the Federal Republic after 1973, others remained, had children, and encouraged their family members to join them. Between 1970 and 1980, the number of people from the six primary "guest worker" countries-Italy, Spain, Portugal, Greece, Yugoslavia, and Turkey-grew from 2.2 million (3.6 percent of the total population of the Federal Republic) to 3.3 million (5.3 percent), with most of that population increase coming from Turkish citizens. The Labor Ministry reacted to the increase by no longer granting work permits to family members who arrived in West Germany after November 30, 1974. Between 1974 and 1979, this ban excluded roughly half a million new arrivals from the legal labor market — making their residence legal, their labor illegal. ${ }^{89}$

New applications for asylum increased sharply during the same period: from 5,289 applications in 1972 to 11,123 in 1976, 33,136 in 1978, and a previously unimaginable 107,818 in $1980 .{ }^{90}$ In response to the rising numbers, the Interior Ministry decided to distribute asylum seekers across the country beginning in 1974, effectively transforming asylum policy from a specifically Bavarian concern into a national issue. In order to alleviate the financial burden on local governments, the Labor Ministry decided, starting in March 1975, to allow asylum seekers to work while waiting for a decision on their application. ${ }^{91}$ The Labor Ministry had intended to reduce costs for local welfare offices, but the fact that this decision followed both the 1973 recruitment halt and the 1974 decision to deny work permits to family members meant that filing an application for asylum suddenly became the only way for foreigners to work legally in the Federal Republic.

The term economic refugee resurfaced in this context, now joined by economic asylum seeker (Wirtschaftsasylant). ${ }^{92}$ The majority of asylum applications in this period came from India,

\footnotetext{
${ }^{87}$ Anselm Doering-Manteuffel and Lutz Raphael, Nach dem Boom: Perspektiven auf die Zeitgeschichte seit 1970 (Göttingen: Vandenhoeck \& Ruprecht, 2008), 35-42.

${ }^{88}$ Günal Incesu, "Der Anwerbestopp vom 23. November 1973 in der massenmedialen Öffentlichkeit der Bundesrepublik Deutschland und der Türkei," Netzwerk Türkei Working Paper No. 8 (Berlin: Netzwerk Türkei, 2010); Karin Hunn, 'Nächstes Jahr kehren wir zurück ...' Die Geschichte der türkischen 'Gastarbeiter' in der Bundesrepublik (Göttingen: Wallstein, 2005), 328-39.

${ }^{89}$ Stokes, "“Fear of the Family,"” 219-81.

${ }^{90}$ Simone Klausmeier, Asylbewerber zum "Scheinasylanten": Asylrecht und Asylpolitik in der Bundesrepublik Deutschland seit 1973 (Berlin: EXpress Edition, 1984), 119.

${ }^{91}$ Münch, Asylpolitik, 65; Poutrus, "Zuflucht im Nachkriegsdeutschland," 887-88.

${ }^{92}$ The term Asylant was initially purely descriptive, but the meaning has shifted over time to include the negative connotation "bogus." For an extended discussion of terminology, see Wolken, "Das Grundrecht auf Asyl," 61-62; Wengeler, "Der sprachliche Umgang," 733-43; Johannes Volmert, "“Asylantendebatte' in Ost und West: Ein Lehrstück über die Instrumentalisierung politischer Vorurteile," in Wer spricht das wahre Deutsch? Erkundungen zur Sprache im vereinigten Deutschland, ed. Ruth Reiher and Rüdiger Läzer (Berlin:
} 
Pakistan, Lebanon, Palestine, and especially Turkey, with Turkish citizens representing half of all new asylum applications by $1980 .{ }^{93}$ Officials often believed that Turkish asylum seekers were trying to manipulate migration categories, switching from family reunion to asylum solely in order to work. ${ }^{94}$ The very fact that Turkish citizens arrived under multiple categories - as guest workers, family members, and asylum seekers - was taken as confirmation that most of these Turkish citizens were lying about their true motives for migration. ${ }^{95}$

Although the Federal Administrative Court had ruled in 1975 that the state could not take its own interests into account when ruling on granting asylum, asylum continued to be difficult to obtain in practice. ${ }^{96}$ The Federal Republic recognized Turkey, a NATO ally and an associate of the European Economic Community, as a "safe country" even after the September 1980 coup there. The asylum bureaucracy operated from a narrow definition of "political persecution" that did not recognize asylum claims made on the basis of state persecution of the Kurdish or Yazidi ethnic groups. ${ }^{97}$ As a result, between January 1979 and August 1983, only 2 percent of all asylum seekers from Turkey were accepted as "genuine refugees." 98

The Federal Republic did not just routinely deny applications for asylum from Turkish citizens, but also sought to keep them from filing applications in the first place. In June 1980, officials introduced an "Emergency Program to Limit the Entrance of 'False' Asylum Seekers" as a temporary measure, supposedly to be revisited in three years. ${ }^{99}$ The "emergency program" consisted of two parts: reinstating a visa requirement for Turkish citizens that had not been in place since November 1953, and removing the supposed incentive to apply for asylum by rescinding work permits for asylum seekers. ${ }^{100}$ These two measures had an immediate effect on the number of asylum seekers, but officials assessing the emergency program tended to single out the work ban as the cause for its success, while ignoring the fact that the visa requirement prevented many from entering West Germany. The

Aufbau Taschenbuch Verlag, 1993), 239-71; Michelle Mattson, "Refugees in Germany: Invasion or Invention?," New German Critique, no. 64 (1995): 61-85.

${ }^{93}$ I stress the fact that these asylum seekers were "Turkish citizens" rather than "Turks" because many were Kurds or Yazidis, who grounded their asylum claims in the fact that they were persecuted on the basis of their identity in Turkey.

${ }^{94}$ See the commission on "false family reunification" in Baden-Württemberg. Landesarchiv BadenWürttemberg, EA 2/303 Bü 209, letter from Innenministerium (IM) Baden-Württemberg to Bundesinnenministerium (BMI) and Innenministerien der Länder, "Betr.: Familiennachzug; hier: Änderung der Geburtsdaten volljähriger Kinder," Feb. 6, 1981; Landtag B-W, Drucksache 8/3206, Nov. 2, 1982.

${ }^{95}$ Stokes, “"Fear of the Family,", 290-92.

${ }^{96}$ Poutrus, "Zuflucht im Nachkriegsdeutschland," 873.

${ }^{97}$ Tim Szatkowski, Die Bundesrepublik Deutschland und die Türkei 1978 bis 1983 (Berlin: Walter de Gruyter, 2016), 112-21.

${ }^{98}$ Ibid., 33.

${ }^{99}$ Ibid., 32.

${ }^{100}$ Visas had previously been introduced for citizens of Pakistan in June 1976 and for citizens of Sri Lanka, Afghanistan, and Ethiopia in March 1980. Visa requirements would also be introduced for India and Bangladesh in July 1980. See BArch B 106/115796, BMI, "Aufhebung des Sichtvermerkzwanges zwischen der Bundesrepublik Deutschland und der Türkei,” Nov. 3, 1953; "Elfte Änderungsverordnung vom 5. Juli 1980 und Auswirkungen der Sichtvermerksplicht für türkische Staatsbürger auf die deutsch-türkischen Beziehungen." 
exclusive focus on the work ban became, in turn, a powerful confirmation of the underlying belief that most asylum seekers were "economic refugees."101

The state moved to make the "emergency" work permit ban permanent-and thus to insulate it from court challenges - in March 1981, when the new "Waiting Period Law" created a "waiting period" for both family members and asylum seekers before they could enter the labor market. Spouses of "guest workers" had to wait for four years and their children two years. The majority of asylum seekers had to wait for two years, with an exception made for those who came from socialist states, who were only required to wait for one year. This distinction reflected the long-held assumption that the economic motives of asylum seekers from the socialist countries were inherently political, and thus more legitimate than those from elsewhere. Each successive draft of the text justifying the "Waiting Period Law" further deemphasized its intended effects on family members and emphasized its intended effects on asylum seekers. The justification that was finally published explained that, ever since the work ban had gone into effect, the percentage of asylum seekers who were Turkish citizens had dropped from 60 percent to 30 percent. The justification failed to mention that visa requirements for Turkish citizens had gone into effect at the same time. ${ }^{102}$ This forced exclusion from the labor market undoubtedly served to delay the integration of those asylum seekers who would stay in Germany, but officials saw this as a price worth paying to deter the imagined "economic refugee" motivated only by the prospect of economic gain.

\section{Local Deterrents for a National Challenge: Excluding the "Economic Refugee" from the Cash Economy}

Although most asylum seekers entered the Federal Republic and filed their applications at one of three locations - the port city of Hamburg, the Frankfurt airport, and West Berlin, where they were able to take advantage of the surprisingly porous border from East to West - they were subsequently distributed throughout the Federal Republic according to a quota system. This practice of redistribution was meant to act as a deterrent to applying for asylum, since asylum seekers could not necessarily choose to stay in communities where they may have had friends, relatives, or a cultural infrastructure. ${ }^{103}$ The federally imposed work ban also meant that local communities found themselves responsible for the financial support of asylum seekers, who were condemned to idleness while waiting for a decision on their application.

Local authorities experimented with different techniques for encouraging asylum seekers to leave before their cases were concluded. Practices such as housing asylum seekers in closed camps and restricting their mobility created an escalating "deterrence spiral" among the

${ }^{101}$ BArch, B 149/67170, Abt. IIa to Herrn Minister, "Betr.: 499. Sitzung des Bundesrates (Plenum) am 8.5.1981; hier: Entwurf eines Sechsten Gesetzes zur Änderung des Arbeitsförderungsgesetzes (Wartezeitgesetz)," May 4, 1981.

${ }^{102}$ Multiple drafts consulted in BArch B 149/54404 and 67170. See esp. BArch B 149/54404, letter from Liselotte Funcke to BMA, "Betr.: Entwurf eines Sechsten Gesetzes zur Änderung des Arbeitsförderungsgesetzes (Wartezeitgesetz)," March 23, 1981; Sprechvermerk IIa 7 Weidenbörner, "Betr.: Entwurf eines Sechsten Gesetzes zur Änderung des Arbeitsförderungsgesetzes (Wartezeitgesetz)," March 23, 1981.

${ }^{103}$ Landesarchiv Berlin (LAB) B Rep 004/3004, letter from Senator für Inneres Berlin to BMI and IM der Länder, "Betr.: Verteilung der Asylbewerber," April 25, 1983. 
federal states, many of which competed to be unattractive locations for finding asylum. ${ }^{104}$ Some spent considerable effort pressuring the federal government to do more to limit the number of asylum seekers. The interior ministers of Bavaria and Baden-Württemberg threatened to repudiate their obligations to house asylum seekers if the federal state did not take radical actions to master the crisis. ${ }^{105}$

Just as it had been after the sealing of the German-German border in 1952, West Berlin was once again the center of the refugee crisis. By 1985, over 50 percent of new asylum seekers were entering via the border between East and West Berlin, the latter still an island city with a weak economy and no space to expand. Heinrich Lummer, the West Berlin senator of the interior and a Christian Democrat, became a proponent of many of the most radical procedures for discouraging asylum seekers, including a plan to offer "temporary asylum" (Asyl auf Zeit), a status that would have required recipients to reapply every two years. ${ }^{106}$ West Berlin was also particularly notorious for making work a condition for financial assistance. Asylum seekers in West Berlin were required to clean streets and subway cars for 1.25 DM per hour, a policy that allowed the city to benefit from migrant labor at far less than its market value. ${ }^{107}$ Finally, West Berlin provided aid to asylum seekers largely as vouchers: 55 DM in cash a month and 185 DM in vouchers, initially in large denominations that did not entitle the person using the voucher to receive any change. ${ }^{108}$ Asylum seekers had to spend nearly one-quarter of their monthly stipend every time they went shopping in order to receive the full value of their aid — a difficult proposition for people who did not have access to refrigerators or even private storage space. The Federal Social Security Act specified that social assistance had to be given in cash unless there was a reason to suspect that the cash was being used for unlawful purposes. ${ }^{109}$ By giving asylum seekers vouchers instead of cash, officials also hoped to deter "economic migrants" who planned to use their welfare payments to send remittances to their home countries. When challenged, officials who defended the use of vouchers often insisted that they did not suspect asylum seekers, but rather the "smugglers" (Schlepper) and human traffickers who demanded cash payment for illegally bringing people into the Federal Republic. ${ }^{110}$

${ }^{104}$ LAB B Rep 004/3004, IM Baden-Württemberg to BMI, "Betr.: Auswirkungen des Asylverfahrensgesetzes," April 13, 1983. For this argument about North Rhein-Westphalia in particular, see Simone Klausmeier, Asylbewerber zum "Scheinasylanten": Asylrecht und Asylpolitik in der Bundesrepublik Deutschland seit 1973 (Berlin: EXpress Edition, 1984). The term deterrence spiral comes from Karakayali, Gespenster, 173.

${ }^{105}$ LAB B Rep 004/3286, letter from Bayerische Minister für Arbeit und Sozialordnung to Berlin Senator für Inneres, Jan. 25, 1985; LAB B Rep 004/3344, letter from Ministerpräsident des B-W to Bundeskanzler, Sept. 5, 1985.

${ }^{106}$ LAB B Rep 004/3343.

${ }^{107}$ Manfred Zuleeg, "Arbeitseinsatz von Asylbewerbern," in Politisches Asyl und Einwanderung: Die Unterbringung von Asylbewerbern in der Bundesrepublik Deutschland im Lichte von historischer Entwicklung und Menschenrecht, ed. Ulrich O. Sievering (Frankfurt/Main: Haag und Herchen, 1984), 205-26.

${ }^{108}$ Ausländerkomitee Berlin (West) e.V., Gast oder Last? Berichte zur Lage der Asylbewerber (Berlin: EXpress Edition, 1981), 16.

${ }^{109}$ Ibid., 86.

${ }^{110}$ Abgeordnetenhaus von Berlin, 68. Sitzung vom 24. Mai 1984, 4089. The figure of the smuggler or human trafficker has a long history in fights to control migration. See Zahra, Great Departure; McKeown, Melancholy Order; idem, "How the Box Became Black: Brokers and the Creation of the Free Migrant," Pacific Affairs 85, no. 1 (2012): 21-45. For the "smuggler" as a figure that enabled restrictive measures in the Federal Republic specifically, see Karakayali, Gespenster. 
In 1984 the Alternative Liste (AL) of West Berlin, a political alliance of left-oppositional groups, began a campaign against the vouchers, in which citizens purchased vouchers from asylum seekers in order to give them access to cash. ${ }^{111}$ Eckhardt Barthel, a Social Democrat in the Berlin Senate, purchased the vouchers through his church and attacked them at public hearings, arguing that they worked as "an instrument of labeling, on the basis of a widespread belief that the asylum seekers are here in order to feast on the blessings of the Federal Republic's prosperity." 112 Initially justified by the widespread belief that asylum seekers were, in fact, "economic migrants" trying to defraud the welfare state, their exclusion from the cash economy also worked to reinforce that belief further.

West Berlin fought the voucher exchange by instructing businesses to refuse to accept vouchers from those customers who were "clearly not asylum seekers." But how was a cashier supposed to decide whether the person handing them a voucher was an asylum seeker? Activists readily recognized the instruction as a tacit order for cashiers to racially profile their customers, and they antagonized the Senate by posing questions such as, "How do you make sure that Polish refugees, who are easily mistaken for Germans because of their appearance ... can use their vouchers?" or "Does the Berlin Senate plan no longer to accept vouchers from Germans, and how does one recognize a German (besides his upright gait)?"113 The West Berlin administration never engaged with this line of questioning, focusing instead on enforcing the requirement that customers who used vouchers carry documentation identifying them as asylum seekers. ${ }^{114}$

When activists asked how cashiers could visually distinguish asylum seekers from those who were "clearly not asylum seekers," they were articulating a criticism about the assumed limits of the national community. What exactly did it mean to look like a "German" as opposed to an "asylum seeker"? This aspect of the anti-voucher campaign points to the ways in which the category of "desirable" refugee was increasingly racialized in this period. Forced migrants in the form of ethnic German repatriates continued to arrive in the Federal Republic, particularly from Poland. Although some Polish citizens applied for political asylum in the Federal Republic, nearly 80 percent of Polish migration to Germany in the late 1970s and 1980s belonged to the category of the ethnic German repatriate. ${ }^{115}$ The repatriates' status as "genuine refugees" was no longer unconditional. In 1977, the Federal Administrative Court ruled that, because conditions had improved in some countries of origin, it could not be automatically assumed that ethnic Germans in those countries

\footnotetext{
${ }^{111}$ The campaign had been successful in Bremen, where the Greens and segments of the SPD cooperated to eliminate vouchers in May 1983. See Archiv Grünes Gedächtnis (AGG) C Berlin I.1, Alternative Liste 1978-1992, Signatur 19 (2/2), Delegiertenrat-Infos 1984, “Antrag des Ausländerbereichs zum DR am 8.2.84," in DR-Info, Feb. 8, 1984.

${ }^{112}$ Abgeordnetenhaus von Berlin, 68. Sitzung vom 24. Mai 1984, 4090.

${ }^{113}$ Ibid., 4097; Drucksache 9/2196, "Nr. 4097 der Abgeordneten Kordula Schulz (AL) über Einkauf mit 'Wertgutscheinen,"” Oct. 10, 1984; Drucksache 9/876, “Nr. 1543 der Abgeordneten Rita Kantemir (AL) über Wertgutscheine für Asylbewerber,” Nov. 3, 1982.

${ }^{114}$ AGG C Berlin I.1, Alternative Liste 1978-1992, Signatur 20 (1/2), Delegiertenrat-Infos 1984, "Protokoll des Delegiertenrates vom 28.11.1984," DR-Info, Nov. 28, 1984; "Kurzprotokoll der GASitzung vom 19. Oktober 1984," DR-Info, Oct. 31, 1984.

${ }^{115}$ Mira Sczygiol Foster, "German Blood-Polish Mind? Exploring the Immigration Histories of Resettlers from Poland in West Germany, 1970s-1990” (PhD diss., University of California, Santa Barbara, 2012), 69-72.
} 
were experiencing an ethnically based "pressure to emigrate."116 One way that an ethnic German repatriate could cast doubt on his or her claim to be a forced migrant was, in fact, to file an application for political asylum, since this was taken to imply that their migration was motivated by economic considerations rather than forced by ethnic discrimination. ${ }^{117}$ Applicants for political asylum from "Turkey, the countries of the Indian subcontinent, black Africa [Schwarzafrika], and the Middle East" were generally assumed to be "primarily economically motivated," whereas those ethnic Germans fleeing communism were still largely considered "genuine refugees"- until a perceived misstep, such as claiming political asylum, demoted them to the category of undesirable "economic refugee."118

As activists contested policy on the ground, the international community was also paying close attention to West German asylum policy. In the summer of 1983, the UNHCR sent a fact-finding mission to the Federal Republic to investigate what it called "dissuasive measures unique in Europe," including the use of in-kind benefits, the ban on legal work, and restrictions on mobility. The final report caused a minor diplomatic incident when it concluded that these measures "affected genuine refugees more than economic migrants," and that the Federal Republic was setting "a dangerous precedent in Europe which may be imitated by other countries."119

In the Federal Republic, by contrast, many officials were coming to believe that the "dangerous precedent" was not to be found in their treatment of asylum seekers, but rather in the pull factor exerted by Article 16 of their own Basic Law: "Persons persecuted on political grounds shall enjoy the right of asylum." An interministerial commission on asylum policy that met in March 1985 struggled to finalize its report because the Justice Ministry, controlled by the Free Democrats, and the Interior Ministry, controlled by the Christian Social Union $(\mathrm{CSU})$, could not agree on the future of Article 16. ${ }^{120}$ Anticipating the creation of a free travel zone within Europe, Interior Ministry officials argued that the Federal Republic could not afford to have a more liberal asylum policy than those of its neighbors. Indeed, many of those neighbors - including Sweden, France, Switzerland, and Denmark — were already pressuring the Federal Republic to do a better job of controlling its borders, since asylum seekers often moved from the Federal Republic to other locations in Europe. ${ }^{121}$ The commission

\footnotetext{
${ }^{116}$ Panagiotidis, “Aussiedlermigration 1950-1989," 926-27.

${ }^{117}$ Koppenfels, "Decline of Privilege," 108. For more detail on changing legal definitions of "pressure to emigrate," see Ulrike Ruhrmann, Reformen zum Recht des Aussiedlerzuzugs (Berlin: Duncker \& Humblot, 1993), 106-14.

${ }^{118}$ LAB B Rep 004/3004, BMI report “Auswirkungen des Asylverfahrensgesetzes vom 16. Juli 1982," April 1983.

${ }^{119}$ UNHCR “Memorandum on Mission to the Federal Republic of Germany," printed in Refugee Survey Quarterly 27, no. 1 (2008): 149, 157-58. Also see Katrin Milzow, “Anatomy of a Crisis: Relations between the United Nations High Commissioner for Refugees and the Federal Republic of Germany from the 1970s to the 1980s," Refugee Survey Quarterly 27, no. 1 (2008): 74-88; Gil Loescher, The UNHCR and World Politics: A Perilous Path (Oxford: Oxford University Press, 2001) 237, 251.

${ }^{120}$ BAK B 137/10816, "Betr.: Interministerielle Kommission 'Asyl' Bezug: Sitzung der Unterarbeitsgruppe am 10. Dezember 1985 im BMI,” Dec. 12, 1985.

${ }^{121}$ Danish Refugee Council, Current Asylum Policy and Humanitarian Principles in the light of the amendment to the Danish Aliens Act of October 17, 1986 (Copenhagen: Danish Refugee Council, 1988); Maryellen Fullerton, "Restricting the Flow of Asylum-Seekers in Belgium, Denmark, the Federal Republic of Germany, and the Netherlands: New Challenges to the Geneva Convention Relating to the Status of Refugees and the European Convention on Human Rights," Virginia Journal of International Law 29, no. 33 (1989): 68-69.
} 
finally published the second part of its report in August 1986, devoting several pages to the differing opinions on Article 16. Some of the commission members insisted that the Federal Republic had to revise Article 16 in order to "regain its capacity for action ... to decide on its own when asylum can and should be granted."122

\section{Conclusion: The 1993 Asylum Compromise and the Permanent Crisis}

The consensus turned in favor of "crisis" - and thus rhetorically mandated decisive actionin the early 1990s in the wake of German unification. The number of yearly arrivals in all categories of forced migration rose sharply in this period. The number of ethnic German repatriates from the Eastern bloc increased as restrictions on exit loosened in the late 1980s, peaking at 397,073 in 1990, a development that placed the Federal Republic's formerly generous acceptance policies for the repatriates under political pressure. The end of the Cold War and the breakup of Yugoslavia also swelled the number of applicants for asylum in the Federal Republic, with the number of people filing an application for asylum reaching a new record high of over 438 thousand in $1992 .{ }^{123}$ The addition of these applicants meant that the Federal Republic had received a total of 1.4 million applications for asylum between 1983 and 1992, far more than the next two countries in Western Europe (France received 318 thousand and Sweden 225 thousand). ${ }^{124}$ Ernst August Farke's 1950 warning that "the lifeboat ... is sinking" returned in the early 1990s as the phrase "the boat is full."

Another important catalyst for the shift toward a consensus of "crisis" was the racist and xenophobic violence that rocked the newly expanded Federal Republic between 1991 and 1993. Although observers had already registered an uptick in violence in the first half of 1990 , the September 1991 riot against a hostel for asylum seekers in Hoyerswerda captured national and international headlines. ${ }^{125}$ Politicians frequently cited these riots and the deadly attacks that followed in Mölln, Rostock, and Solingen as proof that the enlarged Federal Republic had already surpassed its limits of tolerance for difference. They claimed that, in order to integrate the foreigners who were already in the Federal Republic, the state needed a restrictive asylum policy to keep out illegitimate arrivals, often described as "economic refugees."126 Even Arbeitsplatz Deutschland, the state's official magazine for foreign workers, explained the Hoyerswerda riots to its readers as a reaction to the arrival of "economic refugees":

\footnotetext{
${ }^{122}$ LAB B Rep 004/3335, “Bericht der Interministeriellen Kommission 'Asyl' Teil II,” Aug. 19, 1986.

${ }^{123}$ Statistics taken from Bundeszentrale für politische Bildung, "Zahlen und Fakten: Migration” (http:// www.bpb.de/nachschlagen/zahlen-und-fakten/soziale-situation-in-deutschland/61621/migration). There is an excellent account of the Federal Republic's treatment of Yugoslav asylum seekers in Molnar, Yugoslav Migrations, 161-85.

${ }^{124}$ UNHCR, "The State of the World's Refugees 1993: The Challenge of Protection,” Jan. 1, 1993 (https://www.unhcr.org/publications/sowr/4a4c6da96/state-worlds-refugees-1993-challenge-protection.html).

${ }^{125}$ Robert Havemann Archiv der DDR-Opposition, ZRT 2, letter from AG 'Ausländer' to the Zentralen Runden Tisch, Jan. 1990; Bü 064, "Bericht über die Sicherheit für das Leben ausländischer BürgerInnen in Berlin (Ost) in den letzten Monaten," Sept. 11, 1990; MaB 68, "Zusammenstellung von Fällen, in denen vietnamesischen Bürgern von deutschen Bürgern Unrecht geschah," Oct. 16, 1990; RTa 17, "Probleme auf dem Gebiet von Ausländerangelegenheiten in Berlin," May 8, 1990.

${ }^{126}$ Niklaus Steiner, Arguing about Asylum: The Complexity of Refugee Debates in Europe (New York: St. Martin's Press, 2000), 85-92.
} 
It always turns out that most asylum seekers are not politically persecuted at all, but are only emigrating for economic and social reasons, because they seek work and bread ... The costs generated by this flock of economic refugees elicit resentment and rejection in some sections of the population ... but these concerns cannot be equated with the "xenophobia" that is rightly criticized and denounced... It may happen that foreign workers are also victims of violent acts. Even so, one can say: the current wave of xenophobia [Fremdenfeindlichkeit] is not about them, because they are a permanent part of the German economy. ${ }^{127}$

The editorial described the rioting as a reflexive response to economic pressure, naturalizing racist violence as a side effect of market forces. Following the editorial's logic, one might expect that xenophobes make a habit of asking foreigners whether they work before beating them up. The evidence offered by foreigners told a different story: the everyday racism that intensified in the wake of unification was not in the habit of making distinctions between productive and parasitic foreigners, or, for that matter, between Germans of color and foreigners of color. ${ }^{128}$ Asylum seekers and foreign workers might, in fact, have had interests in common when it came to opposing the xenophobic attitudes that the magazine sought to explain, but, in describing the new arrivals as "economic refugees," the author designates a new community of interest. In this conception of the community, the foreigner looking for work is self-evidently a problem-but the foreigner also gains his place in German society entirely through his status as somebody who has work and who is therefore "a permanent part of the German economy." The editorial asserts the primacy of market logic in defining the community, while simultaneously denying supposed "economic refugees" the right to use that logic.

In an attempt to bring this moment of perceived crisis to a close, in December 1992 the CDU/CSU, the FDP, and a large portion of the SPD were able to muster the two-thirds majority needed to pass the asylum compromise, which added a clause to Article 16 of the Basic Law that limited the Federal Republic's obligation to the politically persecuted. The compromise introduced several new restrictions on access to the asylum procedure. Asylum seekers judged to come from a safe country of origin can now be turned away at the border, while those who have entered a safe third country between leaving home and arriving in the Federal Republic can be deported back to that third country. Every country that borders the Federal Republic is considered a "safe third country." These measures placed the Federal Republic on the cutting edge of a global trend toward extraterritorial determination of asylum claims. ${ }^{129}$ The new geography of distant determination also applied to ethnic German repatriates, who were now subject to a yearly quota and required to apply for the new legal status of "late repatriate" (Spätaussiedler) from their current place of residence.

The idea of "safe third countries" for asylum seekers was reiterated in the Dublin Regulation, the Europe-wide asylum policy that went into effect in 1997 and that accords responsibility for asylum seekers to Europe's borderlands. The Italian Coast Guard patrols the Mediterranean because Italy knows that it will be held responsible for the asylum

127 "Wie steht es mit der 'Fremdenfeindlichkeit'?," Arbeitsplatz Deutschland 4 (1991): 2-3.

${ }^{128}$ May Ayim, "Das Jahr 1990. Heimat und Einheit aus afro-deutscher Perspektive," in Entfernte Verbindungen: Rassismus, Antisemitismus, Klassenunterdrückung, ed. Ika Hügel et al. (Berlin: Orlanda Verlag, 1999), 206-20.

${ }^{129}$ For the global trend toward extraterritorial determination, see Alison Mountz, Seeking Asylum: Human Smuggling and Bureaucracy at the Border (Minneapolis: University of Minnesota Press, 2010); Phil Orchard, $A$ Right to Flee: Refugees, States, and the Construction of International Cooperation (Cambridge: Cambridge University Press, 2014), 203-37. 
seekers who reach its shores; Hungary's decision to erect a wall against asylum seekers in the summer of 2015 must be seen in the light of the fact that countries to its West have used Hungary - and the other countries on the European Union's Eastern border-as their own "wall" against asylum seekers who travel overland. The Federal Republic's response to the crisis of the 1980s and early 1990s put in place the institutions and practices that strongly influence the form taken by the migration crisis that has dominated headlines since 2015.

The compromise also legitimated many of the local deterrence strategies that had been controversial in the previous decade, and, in so doing, has guaranteed their continued and even more systematic application in the present. For example, the Asylum Seekers' Benefits Act of 1993 explicitly legitimated the vouchers that activists had once protested in the 1980s when it explicitly allowed local governments to choose whether they would distribute social assistance for asylum seekers as vouchers or as in-kind benefits. The October 2015 Act on the Acceleration of Asylum Procedures includes a new provision that, whenever practicable, benefits for asylum seekers should be provided as vouchers and as in-kind benefits. ${ }^{130}$ Once again, just as in the 1980s, the justification for issuing vouchers is to deny smugglers their ill-gained profits and to deter the unscrupulous, grasping economic migrants driven by "false incentives." 131 There is virtually no public acknowledgment that these practices had been tried a generation earlier without any notable success. Instead, these measures and others like them are invariably presented as unprecedented, exceptional, and imposed by events that have spiraled out of control.

Vouchers are not the only example of an old measure that is back on the political agenda. The current visa requirement for Turkish citizens was first erected in 1980 in order to keep out Turkish asylum seekers. In 2016, Turkey struck a bargain with Europe: it would accept Europe's unwanted Syrian asylum seekers in exchange for a number of concessions, including visa-free travel to Europe for its own citizens. The deal is currently in effect, with Europe trading a small number of its unwanted asylum seekers for recognized refugees who are deemed more desirable, but Turkey has repeatedly threatened to cancel the exchange if Europe fails to grant visa-free travel to Turkish nationals. Nobody seems to have recognized that the visa requirements themselves began as a temporary expedient in order to avert a previous "refugee crisis." How long will it take before the current set of strained solutions are replaced by a new set of "emergency measures"-officially temporary, but endlessly renewed in the face of fresh conditions that are homologous to the old ones but experienced and decried as utterly without precedent?

Within the political culture of the Federal Republic, migration has persistently been understood as an aberration that somehow recurs every single day. The postwar Wirtschaftswunder - perhaps the key legitimating narrative of the Federal Republic — required a steady flow of dislocated labor, beginning first with expellees and then with those East Germans who moved across the German-German border in the late 1940s and 1950s. Employers' access to this mobile labor fueled economic growth and continued to legitimate

\footnotetext{
${ }^{130}$ Winfried Kluth, "Das Asylverfahrensbeschleunigungsgesetz: Zielsetzungen, wesentliche Inhalte, Kritikpunkte," Zeitschrift für Ausländerrecht und Ausländerpolitik 35, no. 10 (2015): 337-42. Also see the video by Flüchtlingsrat Thüringen e.V. and Filmpiraten, "Der alltägliche Rassismus an den Supermarketkassen" (https://vimeo.com/50422072).

${ }^{131}$ Bundesrat Drucksache 446/15, "Entwurf eines Asylverfahrensbeschleunigungsgesetzes," Sept. 29, 2015 .
} 
relatively unrestricted policies on migration for decades. Those migrants initially stigmatized as economic opportunists have repeatedly been able to legitimize themselves—as long as they can become a "permanent part of the German economy." This process of legitimation is already underway for the refugees who arrived in 2015. The president of the Confederation of German Employers' Associations told journalists in December 2018 that Angela Merkel's promise that "we can do it" had proved accurate, since "many migrants" had indeed become a "pillar of the German economy."132

The Federal Republic has never experienced a decade without a "refugee crisis." Even though the presence of new groups of migrants has consistently been depicted in terms of unprecedented "crisis," basic features of these so-called crises-especially the distinction between "genuine" refugees and "economic" migrants— have been part of German political culture since even before the Federal Republic was formally founded in 1949. A petitioner from East Germany pointed to this longer history in February 1990, when he wrote to the Central Round Table, a newly established forum for citizens to discuss reforms in the GDR, in support of a law that would expand the right to asylum in the GDR and allow for dual citizenship for foreign contract workers. "Now everybody is talking about economic refugees," he observed, "But aren't the refugees who left East Germany also economic refugees?"133 The petitioner reminds us that the "economic refugee" has always been a fungible category: it does not inhere in the bodies of individual migrants, nor is it even a feature of their self-understanding. Rather, new regimes of control attach it to new subjects as conditions change. Likewise, "refugee crisis" is the framework in whose terms all such new conditions are continuously interpreted. When the "refugee crisis" finally ends, the Federal Republic, as we have known it, will have ended too.

NORTHWESTERN UNIVERSITY

\footnotetext{
${ }^{132}$ Henning Jauernig, “'Die Integration der Flüchtlinge läuft besser als erwartet,"” Spiegel Online, Dec. 14 2018 (http://www.spiegel.de/wirtschaft/unternehmen/fluechtlinge-die-integration-laeuft-besser-als-erwarteta-1243659.html)

${ }^{133}$ BArch, DA/3/28, letter to Ausländerausschuß des Runden Tisches, Feb. 12, 1990.
} 